\title{
Assessment of Growth and Productivity on Four Black Pepper Varieties (Piper nigrum L.) in Three Target Provinces of Vietnam
}

\author{
Duong Thi Oanh, Nguyen Van Long*, Nguyen Quang Ngoc, Tran Thi Dieu Hien, Pham Thi Hoai, \\ Nguyen Ba Huy
}

Pepper Research and Development Centre, Pleiku City, Viet Nam

Email: *wasigl.long@ymail.com

How to cite this paper: Oanh, D.T., Van Long, N., Ngoc, N.Q., Hien, T.T.D., Hoai, P.T. and Huy, N.B. (2021) Assessment of Growth and Productivity on Four Black Pepper Varieties (Piper nigrum L.) in Three Target Provinces of Vietnam. Engineering, 13, 647-655.

https://doi.org/10.4236/eng.2021.1312046

Received: August 9, 2021

Accepted: December 17, 2021

Published: December 20, 2021

Copyright $\odot 2021$ by author(s) and Scientific Research Publishing Inc. This work is licensed under the Creative Commons Attribution International License (CC BY 4.0).

http://creativecommons.org/licenses/by/4.0/

\begin{abstract}
Black pepper varieties, namely "Vinh Linh", "Lada", "An Do" and "Loc Ninh" were planted in three different ecological regions: Dak Lak, Gia Lai and Dong Nai in order to compare the growth ability, productivity, and quality of peppercorn. The experiments were designed in the Randomized Complete Block Design (RCBD) with four replications. The results of study have been indicated that "Vinh Linh" and "Lada" both varieties performed better crucial parameters of growth, productivity and yield, after 36 months planted. Although having greater growth parameter in the location of Dong Nai province, four varieties showed lower yield than other regions. By contrast, the four pepper types achieved the highest yield in Gia Lai, followed by Dak Lak. With respect to peppercorn quality, "Vinh Linh", "Loc Ninh" and "Lada" achieved requirements of Vietnamese Standard (TCVN 7036:2008) including bulk density: $535.69-612.72 \mathrm{~g} / \mathrm{l}$; piperine: $4.06-4.31 \mathrm{~g} / 100 \mathrm{~g}$ and volatile oil at $2.72-3.16 \mathrm{ml} / 100 \mathrm{~g}$. In contrast, "An Do" variety presented the poorest level of piperine $(3.78 \mathrm{~g} / 100 \mathrm{~g})$, and unachieved requirements.
\end{abstract}

\section{Keywords}

Pepper Varieties, Growth, Yield, Ecology, Vietnam

\section{Introduction}

Black pepper (Piper Nigrum), a permanent plant, is bringing high benefits to boosting social-economic development in Vietnam. Production and exportation of black pepper in Vietnam currently are ranked as the first largest nation in the global market. Vietnam has an area of 131,000 ha and 2.38 ton.ha ${ }^{-1}$ in average yield, accounting for $40 \%$ global pepper products. In 2020 , the country has pro- 
duced annually around 268,500 ton peppercorn and exportation 285,292 ton to global market [1].

Despite having great achievements, pepper industry in Vietnam is assessed as unsustainable development, which is highly likely to have resulted from less diversity of varieties, uncontrolled areas, spread of diseases and climate change. Additionally, results of studies related to pepper breeding are limited and inequal with demands, as a result, fewer pepper types are planted in Vietnam. $P$ iper nigrum in Vietnam has been clarified as three general groups following size of leaf: small leaf, medium leaf and large leaf [1]. The majority of local pepper types is "Vinh Linh", accounting for around 97.1\%, $84.6 \%$ and $100 \%$ in the Western highland, Southern and Northern regions respectively. The crop however, is vulnerably injected by diseases, especially quick death caused by Phytophthora capsici. Similarly, the global market competition is becoming significant; food quality, hygiene and safety are increasingly and strictly controlled which are the detrimental barriers for Vietnamese pepper products.

With respect to sustainable development in the pepper industry, the diversity of pepper types plays a crucial role in improvement of quality and productivity, coping with climate change as well as spreading diseases. Currently, different zones have a few local pepper types which were mostly selected by farmers or immigrated from other places. Furthermore, pepper types often high demand for specifically optimal living conditions, therefore, assessment of potential capabilities of different pepper types at specific regions in Vietnam is absolutely essential to suggest an appropriate group of pepper types for each area.

\section{Materials and Methodology}

Description of the study site: Experiments are conducted at three target provinces, namely Dak Lak, Gia Lai and Dong Nai, and four varieties: "Vinh Linh", "Loc Ninh", "Lada” and "An Do" during a three year period (2018-2020). Several details of sites are described on Table 1.

Table 1. Characterization of observation sites in Vietnam.

\begin{tabular}{cccc}
\hline \multirow{2}{*}{ Variable location } & \multicolumn{3}{c}{ Experimental sites } \\
\cline { 2 - 4 } & Gia Lai & Dak Lak & Dong Nai \\
\hline District & Ia Grai & Buon Ma Thuot & Trang Bom \\
Altitude (m asl) & 750 & 650 & 15 \\
Live support types & Leucaena leacocephala & Casia siamea & Wrightia annamensis \\
Soil types & Bazan & Bazan & Bazan \\
Average temperature $\left({ }^{\circ} \mathrm{C}\right)$ & 22.6 & 24.2 & 26.8 \\
Annual rainfall (mm) & 2329.3 & 1630.6 & 2158.9 \\
Dry months & 6 & 6 & 6 \\
Relative humidity $\%$ & 81.5 & 81.0 & 80.5
\end{tabular}




\section{Experimental design:}

A two-factor experiment was designed following RCBD (randomized complete block design model), four replications with four different pepper types in three regions. A replication includes 50 plants, as 200 plants per a treatment. Total of 800 crops were planted in a region, equally 2400 plants in the study; a density of 1.600 vines $\cdot \mathrm{ha}^{-1}$.

Agricultural practices in the research are followed by Vietnamese agricultural practice of MARD [2].

Data collection: Study has mostly investigated fundamental factors including general characteristics, yield and quality after 36 months planted. Total of 40 plantations of each pepper type in a treatment and a region were selected randomly and measured:

- Vegetative characters: Number of main shoots.vine ${ }^{-1}$, number of literal branches on one-meter main shoot, length of four literal branches $(\mathrm{cm})$ at four directions measuring from the base to the tip of the branch.

- Berry characters:

Number of spike/literal branch: Selected randomly four literal branches (at the middle of plant) at four different directions and counted total spikes on a branch. Spike length: Ten spikes in a direction at the middle of plant were picked randomly and measured from the base of first pedicel to the tip of spike. The work is repeated with the rest of three directions.

Number of berries-spike ${ }^{-1}$ : Total fruits on the spike, the process is taken all spike which use to measured spike length above.

- Yield of peppercorn was harvested in 2020, when plant age was 3 years old, and measured separately all plants on the experiment in order to assess the dry

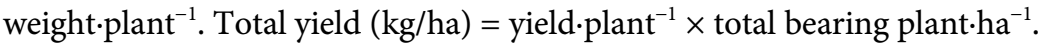

- Quality: Samples were collected from four treatments in three locations. Pepper quality was analyzed several factors: bulk density of peppercorn (g/l) following standard of TCVN 4045:1993 [3]; piperine (g/100g) following standard of ISO 5564:1982 [4]; Volatile Oil (ml/100g) following standard of ISO 6571:2008 [5].

Data analysis: Data is collected and analysed ANOVA using SAS 9.1 statistical software.

\section{Results of study}

\section{1) Growth characters of four pepper types}

Table 2 indicated anaverage main shoots per vine ranging from 3.45 to 6.98 shoots. "Vinh Linh" and "Lada" both have higher and significant difference in the number of main shoots in three regions, in comparison with others $(\mathrm{p}<$ 0.01). "Loc Ninh", by contrast, has the lowest number of shoots $\cdot v_{i n e}{ }^{-1}$ with an average of 3.45 shoots. Additionally, it is noticeable that crops which planted in Dong Nai, have performed better in main shoots than the rest of two regions. 
Table 2. Assessment on growth characteristics of four pepper types at three provinces after 36 months planted.

\begin{tabular}{|c|c|c|c|c|}
\hline \multirow{2}{*}{ Factor A (pepper types) } & \multicolumn{3}{|c|}{ Factor B (regions) } & \multirow{2}{*}{ Mean A } \\
\hline & Dak Lak & Gia Lai & Dong Nai & \\
\hline \multicolumn{5}{|l|}{ Number of main shoots/vine } \\
\hline “An Do" & $4.63^{\mathrm{e}}$ & $4.68^{\mathrm{de}}$ & $6.35^{\mathrm{c}}$ & $5.22^{\mathrm{B}}$ \\
\hline "Lada" & $7.58^{\mathrm{b}}$ & $5.48^{\mathrm{d}}$ & $7.90^{\mathrm{ab}}$ & $6.98^{\mathrm{A}}$ \\
\hline "Loc Ninh" & $2.38^{\mathrm{g}}$ & $2.73^{\mathrm{g}}$ & $5.25^{\mathrm{de}}$ & $3.45^{\mathrm{C}}$ \\
\hline "Vinh Linh" & $8.68^{\mathrm{a}}$ & $3.53^{\mathrm{f}}$ & $8.45^{\mathrm{a}}$ & $6.88^{\mathrm{A}}$ \\
\hline Mean B & $5.81^{\mathrm{B}}$ & $4.10^{\mathrm{C}}$ & $6.99^{\mathrm{A}}$ & \\
\hline & \multicolumn{3}{|c|}{$\mathrm{CV}=10.35 \% ; \mathrm{F}_{\mathrm{B}}^{* *} ; \mathrm{F}_{\mathrm{A}}^{* *} ; \mathrm{F}_{\mathrm{A} \times \mathrm{B}}^{* *}$} & \\
\hline \multicolumn{5}{|c|}{ Number of literal branches (branch/1 meter shoot) } \\
\hline “An Do" & $10.85^{\mathrm{g}}$ & $19.90^{\mathrm{de}}$ & $32.50^{\mathrm{bc}}$ & $21.08^{\mathrm{B}}$ \\
\hline "Lada" & $13.45^{\mathrm{fg}}$ & $22.85^{\mathrm{d}}$ & $33.45^{\mathrm{b}}$ & $23.25^{\mathrm{B}}$ \\
\hline "Loc Ninh" & $7.00^{\mathrm{h}}$ & $16.55^{\mathrm{ef}}$ & $29.85^{c}$ & $17.80^{\mathrm{C}}$ \\
\hline "Vinh Linh" & $18.50^{\mathrm{e}}$ & $23.05^{\mathrm{d}}$ & $41.00^{\mathrm{a}}$ & $27.52^{\mathrm{A}}$ \\
\hline Mean B & $12.45^{\mathrm{C}}$ & $20.59^{\mathrm{B}}$ & $34.20^{\mathrm{A}}$ & \\
\hline \multicolumn{5}{|c|}{$\mathrm{CV}=10.30 \% ; \mathrm{F}_{\mathrm{B}}^{* *} ; \mathrm{F}_{\mathrm{A}}^{* *} ; \mathrm{F}_{\mathrm{A} \times \mathrm{B}}^{* *}$} \\
\hline \multicolumn{5}{|l|}{ Literal's length $(\mathrm{cm})$} \\
\hline “An Do" & $56.00^{\mathrm{bc}}$ & $35.40^{\mathrm{f}}$ & $60.20^{\mathrm{ab}}$ & $50.53^{\mathrm{B}}$ \\
\hline "Lada" & $63.62^{\mathrm{a}}$ & $44.28^{\mathrm{e}}$ & $50.85^{\mathrm{d}}$ & $52.92^{\mathrm{AB}}$ \\
\hline "Loc Ninh" & $52.09^{\mathrm{cd}}$ & $30.24^{\mathrm{g}}$ & $45.15^{\mathrm{e}}$ & $42.49^{\mathrm{C}}$ \\
\hline "Vinh Linh" & $62.59^{\mathrm{a}}$ & $44.09^{\mathrm{e}}$ & $56.75^{\mathrm{bc}}$ & $54.48^{\mathrm{A}}$ \\
\hline Mean B & $58.57^{\mathrm{A}}$ & $38.50^{\mathrm{C}}$ & $52.24^{\mathrm{B}}$ & \\
\hline \multicolumn{5}{|c|}{$\mathrm{CV}=6.78 \% ; \mathrm{F}_{\mathrm{B}}^{* *} ; \mathrm{F}_{\mathrm{A}}{ }^{* *} ; \mathrm{F}_{\mathrm{A} \times \mathrm{B}}{ }^{* *}$} \\
\hline
\end{tabular}

Noted: Means bearing the same letter within the table are not significant different according to Least Significant Difference Test. CV: Coeficient of Variation

There are significant differences in the of quantity and length of literal branches between varieties and regions. "Vinh Linh", a pepper type dominates strongly on the number of literal branches per one meter shoot (an average of 27.52 branches) and literal branch's length $(54.48 \mathrm{~cm})$ in three locations; followed by "Lada", and "An Do".

With regard to locations also influence significantly on branch development and growth of pepper types $(\mathrm{p}<0.01)$. Dak Lak, the crops performed the lowest number of literal branches (12.45 branches) compared to Gia Lai and Dong Nai. Four pepper cultivars grown in Dong Nai shows better number of literal branches.

Spike length and number of berries.spike ${ }^{-1}$ are two fundamental factors contributing to the yield of pepper. Pepper types were grown in Dak Lak have 
Table 3. The spike's length and number of berries per spike of four different pepper types in three regions after 36 months planted.

\begin{tabular}{|c|c|c|c|c|}
\hline \multirow{2}{*}{ Factor A (pepper types) } & \multicolumn{3}{|c|}{ Factor B (regions) } & \multirow{2}{*}{$\begin{array}{l}\text { Mean A } \\
\text { (region) }\end{array}$} \\
\hline & Dak Lak & Gia Lai & Dong Nai & \\
\hline \multicolumn{5}{|l|}{ Spike' length $(\mathrm{cm})$} \\
\hline "An Do" & $9.90^{\mathrm{a}}$ & $9.10^{\mathrm{abc}}$ & $9.60^{\mathrm{ab}}$ & $9.53^{\mathrm{A}}$ \\
\hline "Lada" & $7.09^{f}$ & $8.57^{\text {cde }}$ & $7.93^{\mathrm{e}}$ & $7.86^{\mathrm{C}}$ \\
\hline "Loc Ninh" & $8.90^{\mathrm{bcd}}$ & $8.31^{\text {cde }}$ & $6.83^{\mathrm{f}}$ & $8.01^{\mathrm{BC}}$ \\
\hline "Vinh Linh" & $8.78^{\text {bcde }}$ & $8.08^{\mathrm{de}}$ & $8.55^{\text {cde }}$ & $8.47^{\mathrm{B}}$ \\
\hline Mean B & $8.67^{\mathrm{A}}$ & $8.52^{\mathrm{AB}}$ & $8.23^{\mathrm{B}}$ & \\
\hline \multicolumn{5}{|c|}{$\mathrm{CV}=5.18 \% ; \mathrm{F}_{\mathrm{B}}^{* *} ; \mathrm{F}_{\mathrm{A}}^{* *} ; \mathrm{F}_{\mathrm{B} \times \mathrm{A}}{ }^{* *}$} \\
\hline \multicolumn{5}{|l|}{ Berries/spike (berry) } \\
\hline "An Do" & $52.50^{\mathrm{a}}$ & $25.20^{\mathrm{e}}$ & $42.60^{c}$ & $40.10^{\mathrm{A}}$ \\
\hline "Lada" & $40.10^{c}$ & $24.70^{\mathrm{e}}$ & $35.30^{\mathrm{d}}$ & $33.37^{\mathrm{C}}$ \\
\hline "Loc Ninh" & $54.35^{\mathrm{a}}$ & $28.16^{\mathrm{e}}$ & $28.20^{\mathrm{e}}$ & $36.90^{\mathrm{B}}$ \\
\hline "Vinh Linh" & $47.80^{\mathrm{b}}$ & $27.90^{\mathrm{e}}$ & $38.00^{\mathrm{cd}}$ & $37.90^{\mathrm{AB}}$ \\
\hline \multirow[t]{2}{*}{ Mean B } & $48.69^{\mathrm{A}}$ & $26.49^{\mathrm{C}}$ & $36.03^{\mathrm{B}}$ & \\
\hline & \multicolumn{3}{|c|}{$\mathrm{CV}=7.25 \% ; \mathrm{F}^{* *} ; \mathrm{F}_{\mathrm{A}}^{* *} ; \mathrm{F}_{\mathrm{B} \times \mathrm{A}}^{* *}$} & \\
\hline
\end{tabular}

Noted: Means bearing the same letter within the table are not significant different according to Least Significant Difference Test. CV: Coeficient of Variation.

considerably differences in spike's length and number of berries-spike ${ }^{-1}$ compared to other locations. "An Do" and "Vinh Linh" varieties both presented better measurements on the berries and length of spike in three different regions (see Table 3). "Lada", despite of good growth, measures of spike's length and number berries.spike ${ }^{-1}$ were the lowest.

\section{2) Yield and quality of four pepper types}

Figure 1 shows that "Vinh Linh" and "Lada" have presented higher yield than others. Additionally, all crops performed the great productivity in the locations of Gia Lai and Dak Lak provinces. Overall, "Lada" achieved the highest yield (702.04 $\mathrm{kg} / \mathrm{ha}$ ) in three different provinces, followed by "Vinh Linh" and "An Do" and "Loc Ninh" with $675.86 \mathrm{~kg} / \mathrm{ha}, 455.87 \mathrm{~kg} / \mathrm{ha}$ and $366.50 \mathrm{~kg} / \mathrm{ha}$ respectively.

Bulk density is a physical factor which determines berry weight. Basing on bulk density and standard of TCVN 7036:2008, peppercorn which is produced from "An Do" and "Lada" cultivars are classified as special; "Vinh Linh" is graded I; and "Loc Ninh" is graded II. Pepper types in Gia Lai achieved better bulk density (600.56 g/liter) than Dak Lak and Dong Nai (see Table 4).

Piperine and volatile oil directly affect the spiciness and aroma of peppercorn. Increase in the level of piperine and volatile oil leads to improvement in quality and value of peppercorn. According to TCVN 7036:2008, peppercorn which 


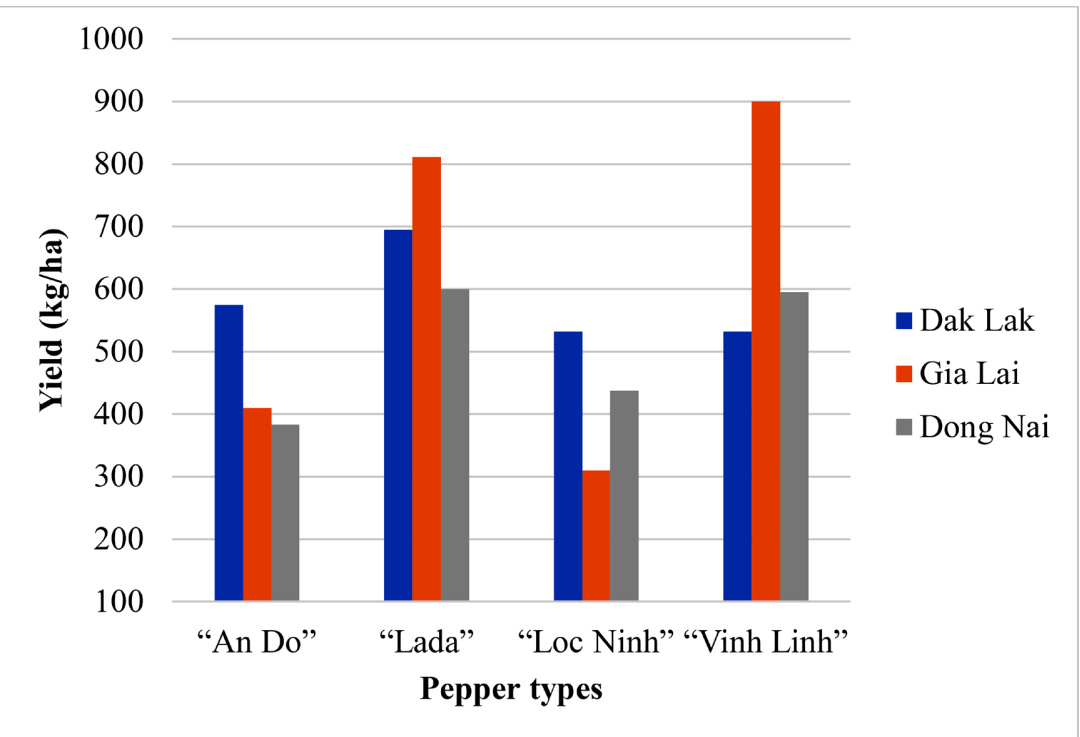

Figure 1. The average yield of four pepper varieties in three locations after 36 months planted.

Table 4. Bulk density of peppercorn of four pepper types in three locations (g/litter) after 36 months planted.

\begin{tabular}{ccccc}
\hline \multirow{2}{*}{ Factor A (variety) } & \multicolumn{3}{c}{ Factor B (regions) } & \multirow{2}{*}{ Mean A } \\
\cline { 2 - 4 } & Dak Lak & Gia Lai & Dong Nai & \\
\hline “An Do" & $633.75^{\mathrm{a}}$ & $601.32^{\mathrm{c}}$ & $575.00^{\mathrm{e}}$ & $603.36^{\mathrm{B}}$ \\
"Lada" & $640.00^{\mathrm{a}}$ & $622.22^{\mathrm{b}}$ & $575.95^{\mathrm{e}}$ & $612.72^{\mathrm{A}}$ \\
"Loc Ninh" & $500.00^{\mathrm{h}}$ & $564.93^{\mathrm{f}}$ & $542.15^{\mathrm{g}}$ & $535.69^{\mathrm{D}}$ \\
"Vinh Linh" & $500.00^{\mathrm{h}}$ & $613.76^{\mathrm{b}}$ & $591.00^{\mathrm{d}}$ & $568.25^{\mathrm{C}}$ \\
Mean B & $568.44^{\mathrm{B}}$ & $600.56^{\mathrm{A}}$ & $571.03^{\mathrm{B}}$ & \\
& $\mathrm{CV}=1.09 \% ; \mathrm{F}_{\mathrm{B}}{ }^{* *} ; \mathrm{F}_{\mathrm{A}}^{* *} ; \mathrm{F}_{\mathrm{B} \times \mathrm{A}}$ & \\
\hline
\end{tabular}

Noted: Means bearing the same letter within the table are not significant different according to Least Significant Difference Test. CV: Coeficient of Variation.

Table 5. Content of piperine and Volatile oil in peppercorn of four pepper types after 36 months planted.

\begin{tabular}{ccc}
\hline Pepper types & Piperine $(\mathrm{g} / \mathbf{1 0 0 g})$ & Volatile Oil $(\mathrm{ml} / \mathbf{1 0 0 g})$ \\
\hline "An Do" & 3.78 & 4.02 \\
"Lada" & 4.06 & 2.72 \\
"Loc Ninh" & 4.08 & 3.16 \\
"Vinh Linh" & 4.31 & 2.72 \\
\hline
\end{tabular}

produced from "An Do" variety was not achieved the requirement of Vietnamese Standard (content of piperine and volatile oil are required minimizing 4 g/100g and 2\%). Table 5 presents that three varieties: "Lada", "Vinh Linh" and 
"Loc Ninh" have been achieved the Vietnamese Standard.

\section{Discussion}

Many researchers have concluded that the differences on growth and yield of pepper types mostly depend on three main factors: genotypes, environment, and agricultural practices [6] [7] [8]. In this study, because of all experiments are applied as the same agricultural practices (fertilizers, pesticides, and fungicides), as a result, two main factors influencing on pepper developments are determined as climate conditions and genotypes.

The same varieties, however, different distribution of annual rainfall in the three regions have also incidence in pollination, length of spike, number of berry.spike ${ }^{-1}$ and spike shedding and those factors significantly impact potential yield of pepper [8]. This could be strongly supported the arguments that temperature and humidity in Gia Lai and Dak Lak are more favourable for black pepper, compared to Dong Nai where has higher temperature and lower humidity. Furthermore, the flowering stage occurs from May to August as rainy season in Gia Lai and Dak Lak, as optimal conditions for flowering, pollination, and spike setting. This is highly likely to be a crucial reason to support why pepper plantations in two provinces have higher yield in comparison with Dong Nai. The findings are similar to the research of Sivaraman, Kandiannnan [9]. Authors reported that the environmental factors in terms of elevation, soil fertility, cultural practices, temperature, rainfall and climatic conditions during flowering, fruit set and development all significantly influence in black pepper yield.

Although spike length and number of fruit.spike ${ }^{-1}$ rely on genetic and climate factors, by contrast, fruits.spike ${ }^{-1}$ are significantly fluctuated in growing environmental conditions which was highlighted by many studies [10] [11]. At the same time, yield and quality of peppercorn are influenced by climate conditions, agricultural practices and genetic makeup, which were presented by Zachariah, Mathew [12]; Chandran, Amma [13]; Ghodki and Goswami [14] and Ibrahim, Sukumara Pillai [10]. The findings of the study are also similar to the results of obvious researches in Vietnam. Nhung, Oanh [15]; Oanh, Huy [16]; Quyen, Dan [17] and Ton, Binh [18] all of them agreed that "Vinh Linh" and "Lada" both varieties not only achieve great measures of growth, but also have higher yield and quality of peppercorn.

\section{Conclusion}

Research has investigated and compared growth parameters, yield and peppercorn quality of four pepper types in three different locations in Vietnam. Pepper varieties performed significant differences on these measures. "Vinh Linh" and "Lada" dominated on the three regions after 36 months planted and all pepper types achieved greater yield in the regions of Gia Lai and Dak Lak. With regard to quality, three pepper types overcome the requirement of Vietnamese Standard, except "An Do" variety. Consequently, "Vinh Linh", "Lada" and "Loc Ninh" 
are highly likely to be advised to plant popularly in these areas. Besides, due to limited time and resources, plants do not have adequate time to perform potential growth, yield and quality of peppercorn, therefore, continuity of the study for next several years is necessary.

\section{Conflicts of Interest}

The authors declare no conflicts of interest regarding the publication of this paper.

\section{References}

[1] Department of Crop Production (2021) Report of Preliminary Conference on Crop Production for Winter-Spring Crop 2020-2021, Implementation of Summer-Autumn Crop Plan and 2021 Crop in the South Central Coast and Central Highlands. Ninh Thuan, 2021.

[2] Ton, N.T., et al. (2009) Research on Sellecting Varieties and Advanced Technologies for Sustainable Development of Black Pepper Industry. Institute of Agricultural Science for Shouthern Viet Nam: Institute of Agricultural Science for Shouthern Viet Nam.

[3] MARD (2015) The Process of Black Pepper Cultivation 2015: Decision Number 730/BNN-PTNT 5/3/2015 of Ministry of Agriculture and Rural Development, Vietnam.

[4] Ministry of Science and Technology (1993) Vietnamese Standard of Piper nigrum L.-TCVN 4045:1993. 1993.

[5] ISO (1982) ISO 5564: 1982 Black Pepper and White Pepper, Whole or Ground-Determination of Piperine Content-Spectrophotometric Method. https://www.iso.org/standard/11634.html

[6] ISO (2008) ISO 6571: 2008 Spices, Condiments and Herbs-Determination of Volatile Oil Content (Hydrodistillation Method). https://www.iso.org/standard/41299.html

[7] Pannaga, T., et al. (2021) Evaluation of Black Pepper (Piper nigrum L.) Cultivars for Yield and Quality Parameters under Hill Zone of Karnataka. Journal of Pharmacognosy and Phytochemistry, 10, 1497-1500.

[8] Krishnamurthy, K., et al. (2011) Trends in Climate and Productivity and Relationship between Climatic Variables and Productivity in Black Pepper (Piper nigrum).

[9] Bermawie, N., et al. (2019) Morphological Characteristics, Yield and Quality of Black Pepper Ciinten Variety in Three Agro Ecological Conditions. IOP Conference Series: Earth and Environmental Science, 292, 012065. https://doi.org/10.1088/1755-1315/292/1/012065

[10] Sivaraman, K., et al. (1999) Agronomy of Black Pepper (Piper nigrum L.). Journal of Spices and Aromatic Crops, 8, 1-18.

[11] Ibrahim, K., Pillai, V.S. and Sasikumaran, S. (1985) Variability, Heritability and Genetic Advance for Certain Quantitative Characters in Black Pepper.

[12] Ravindran, P. (2000) Management of Pepper in Indonesia, in Black Pepper. CRC Press, London, 249-262. https://doi.org/10.1201/9780203303870

[13] Zachariah, J.T., Mathew, P. and Gobinath, P. (2005) Chemical Quality of Berries from Black Pepper Varieties Grafted on Piper colubrinum.

[14] Chandran, J., et al. (2012) Effect of Enzyme Assisted Extraction on Quality and Yield 
of Volatile Oil from Black Pepper and Cardamom. Food Science and Biotechnology, 21, 1611-1617. https://doi.org/10.1007/s10068-012-0214-y

[15] Ghodki, B.M. and Goswami, T. (2016) Effect of Grinding Temperatures on Particle and Physicochemical Characteristics of Black Pepper Powder. Powder Technology, 299, 168-177. https://doi.org/10.1016/j.powtec.2016.05.042

[16] Nhung, N.T., Oanh, D.T. and Long, N.V. (2019) Assessment of Growth and Productivity of Some Pepper Varieties in Gia Lai. 2019: Black Pepper Research and Development Centre-The Western Highland Agriculture and Forestry Science Institute, Vietnam.

[17] Oanh, D.T., Huy, N.B. and Hoai, P.T. (2020) Assessment of Growth and Productivity of Some Pepper Varieties in Gia Lai. 2020: Black Pepper Research and Development Centre-The Western Highland Agriculture and Forestry Science Institute, Vietnam.

[18] Quyen, N.T., et al. (2021) Research on Pepper Varieties and Intergrated Technical for Sustainable Pepper Development. 2021: Black Pepper Research and Development Centre-The Western Highland Agriculture and Forestry Science Institute, Vietnam.

[19] Ton, N.T., et al. (2009) Research on Sellecting Varieties and Advanced Technologies for Sustainable Development of Black Pepper Industry. 2009, Institute of Agricultural Science for Shouthern Viet Nam: Institute of Agricultural Science for Shouthern Viet Nam. 